\title{
Effect of leaf extracts of Cymbopogon Citratus, Chromolaena Odorata and Newbouldia Laevis on the Dioscorea Alata rot
}

\author{
Okigbo RN and Ezebo RO* \\ Department of Botany, Faculty of Bioscience, Nnamdi Azikiwe University, P.M.B., 5025, Awka, Anambra State, Nigeria
}

\begin{abstract}
Fungitoxic effect of ethanol and cold-water extracts of Cymbopogon citratus, Chromolaena odorata, and Newbouldia laevis were determined in vitro on causative agents of water yam rot. The microbial pathogens obtained were Botryodiplodia theobromae, Aspergillus niger, Fusarium solani, Penicillium spp and Rhizopus stolonifer. Ethanol and cold-water extracts of the plants were prepared by adding separately $10 \mathrm{~g}, 20 \mathrm{~g}, 30 \mathrm{~g}, 40 \mathrm{~g}$ and $50 \mathrm{~g}$ of the leaf powder of Cymbopogon citratus, Chromolaena odorata and Newbouldia laevis into $100 \mathrm{ml}$ of ethanol and cold water respectively. All extracts of the plant materials at varying concentrations showed antifungal activity against the fungal tested. The antimycotic effect of the plant extracts varied with the solvent of extraction, extraction concentration and the test organisms. Ethanol extracts of Cymbopogon citratus had between slightly (11.10-18.00\%) and moderately effective (29.65-46.00\%) inhibition on the mycelia growth of all the fungi tested. Also, cold water extracts of Cymbopogon citratus depicted slightly (4.00-19.92\%) and moderately effective (37.7-39.00\%) inhibition on all the fungi tested. Ethanol extracts of Chromolaena odorata had between slightly (11.18-15.03\%) and moderately effective (29.65-41.00\%) on all the fungal pathogens. Also, cold water extracts of Chromolaena odorata showed between slightly to moderately effective inhibition ranging from (8.00-19.05\%) to (21.00-39.00\%) respectively. Ethanol extracts of Newbouldia laevis showed between slightly (0.35-19.10\%) and moderately effective (22.90-49.11\%) inhibition on all the fungi tested. Cold water extracts of Newbouldia laevis showed between slightly to moderately effective inhibition ranging from (3.40-19.00\%) to (22.00-44.01\%) respectively. The most fungitoxic of all the extracts was observed with the $50 \%$ ethanol extract of Newbouldia laevis which showed significant $(\mathrm{P}<0.05)$ inhibition on all the test fungal pathogens. Ethanol plant extracts showed higher antifungal activity against the test pathogens than the cold-water plant extracts. Analysis of Variance (ANOVA) was employed and the Duncan's Multiple Range Test (DMRT) was also used to test the difference among treatments. Phytochemical screening of the leaf extracts revealed the presence of saponins, alkaloids, tannins and flavonoids in the extracts but at different concentrations. This study indicated that Cymbopogon citratus, Chromolaena odorata and Newbouldia laevis were able to suppress rot-causing fungi of water yam deterioration. The fungitoxic potentials of these extracts on water yam rots can provide an alternative to synthetic fungicides since it is less expensive, environmental friendly and easy to prepare.
\end{abstract}

\section{Introduction}

Yam (Dioscorea spp.) a monocotyledonous plant, belonging to the family Dioscoreaceae, is a herbaceous annual climbing plant with edible underground tubers [1]. It is the most important food crops in West Africa [2,3] and form an important food source in other tropical countries including East Africa, the Carribbean, South America, India and South-East Asia [2,3]. Okigbo [3] estimated that the world production of yams is around 20 million tonnes per year. The greater part of the world yam production (over 90\%) is derived from West Africa [2,3] and Nigeria alone produces three-quarters of the world total output of yam $[3,4]$.

Of the ten-cultivated species of yam, the six most important in Nigeria are: Dioscorea rotundata Poir (white yam), Dioscorea alata L. (water yam), Dioscorea cayenensis Lam. (yellow yam), Dioscorea dumetorum (Kunth) Pax. (cluster or bitter yam), Dioscorea bulbifera L. (aerial yam) and Dioscorea esculenta (Loir) Bark (Chinese yam) [5,6].

Water yam (Dioscorea alata) is the most economically important yam species which serve as a staple food for millions of people in tropical and subtropical countries [2,7]. Dioscorea alata is a crop with potential for increased consumer demand due to its low sugar content necessary for diabetic patients [8].

According to Scott et al., water yam (Dioscorea alata L.) is the most widely distributed species of yam, though the total quantity produced is less than that of white yam. Water yam (D. alata L.) is grown widely in tropical and subtropical regions of the world. They are plants yielding tubers and contain starch between $70 \%$ and $80 \%$ of dry matter $[9,10]$.

The tuber is the only economically important part of the crop and according to Sangoyomi [11], it is consumed roasted, fried, boiled, pounded or as flour which can be reconstituted with hot water. Yam tubers are of a very high value, as in food, where it is a major source of carbohydrate, minerals of calcium, phosphorus, iron and vitamins $\mathrm{B}$ and $\mathrm{C}[2,12]$. According to Olayide and Heady [13], the demand for yam in Nigeria has always exceeded its supply.

In spite of the importance of yams as major staple food and its socio-cultural value in the lives of the people of the West and Central Africa sub-region, research and documentation on this important staple food crop is very limited [11].

Correspondence to: Ezebo RO, Department of Botany, Faculty of Bioscience, Nnamdi Azikiwe University, P.M.B., 5025, Awka, Anambra State, Nigeria, Tel: 08060044563,E-mail: esau_056@yahoo.com

Key words: effect, leaf extracts, Cymbopogon citratus, Chromolaena odorata, Newbouldia laevis, Dioscorea alata rot

Received: November 21, 2017; Accepted: December 22, 2017; Published: December 26, 2017 
During prolonged storage, considerable losses occur [11]. Losses up to $10-20 \%$ may be observed in the first three months and $30-60 \%$ after six months in the yam barns $[2,14,15]$. Causes of storage losses are rotting, pests and sprouting. However, rotting causes the greatest amount of losses and it is due mostly to the effects of fungi, bacteria and nematodes. Fungi are the most important and have been reported to be responsible for $80 \%$ of all storage rots of yam tubers in West Indies and $57-77 \%$ in Nigeria [16].

The principal microorganisms associated with yam include: Botryodiplodia theobromae Pat., Fusarium oxysporum Schlecht, Penicillium oxalicum Currie and Thom., Aspergillus niger Van Tiegh and Aspergillus tamari Kita [5,17-19]. Microorganisms that caused rot did so at a high relative humidity and temperatures of $25-39^{\circ} \mathrm{C}$ [5] and some were more aggressive at a higher temperature of $35^{\circ} \mathrm{C}$.Yam rots usually start in the soil and progress in storage, which occur when infected tubers do not yet have any sign of external symptoms [12].

The widespread use of medicinal plants (both indigenous and alien) can be traced to the occurrence of natural products with medicinal properties in plants and their ability to synthesize a variety of chemical compounds [20-23]. The use of chemicals has helped in the control of rots but due to the identifiable problems which include: biodegradation, pollution, chemical residues, phytotoxicity, high cost, development of resistance in target organism, a times non availability and then being hazardous to man and his environment renders them either slow to adapt or farmers have totally failed to adopt them for one cultural reason or the other $[24,25]$. Recently, considerable efforts are directed at exploring the potentials of plant extracts as alternative to synthetic chemicals. These plant extracts are readily available, affordable, nonphytotoxic and are biodegradable thus being friendly to man and his environment [26-28].

Lemongrass (Cymbopogon citratus DC. Ex Nees) Stapf of family, Poaceae, is a perennial grass plant widely distributed worldwide and most especially in tropical and subtropical countries [29]. Several reports have linked its origin to Asia (Indochina, Indonesia and Malaysia), Africa and the America. The plant could grow up to 6 inch high and its bulb-like stems consist of terete and glabrous linearly venated sheathed leaves with narrow base and acute apex. The leaf height is about $10^{\circ} \mathrm{Cm}$ in length and $2 \mathrm{~cm}$ in width. When squeezed, the leaves usually produce yellow or amber coloured, aromatic essential oil [30].

Lemongrass also enjoyed wide application in folk medicine [31]. Traditionally, tea made from lemongrass leave is popular among countries of South America, Asia and West Africa having been widely utilized as antiseptic, antifever, antidyspeptic, carminative and antiinflammatory effects. Others are febrifuge, analgesic, spasmolytic, antipyretic, dieuretic, tranquilizer and stomachic agent [30,32-35].

Chromolaena odorata (L.) R.M. King and Robinson formerly known as Eupatorium odoratum (siam weed) of family, Asteraceae, is a herbaceous perennial that forms dense tangled bushes about $1.5-2.0 \mathrm{~m}$ in height and has a characteristic aromatic smell [36]. It is considered to be a significant economic and ecological burden to many tropical and subtropical regions of the world where it impacts negatively on agriculture, biodiversity and livelihoods [37,38].

Following its introduction into West Africa in the 1930's [39] and South Africa in the 1940's [40], the species has spread into many countries on the continent [41].

The medicinal use of Chromolaena odorata has also not gone unnoticed. The astringent properties of the leaf extracts of Chromolaena odorata on the blood vessel [42] has made it a popular plant in the prevention of blood loss from wounds, also its antimicrobial properties have made it a popular choice in disinfecting and treating open wounds [43]. The 8 anthelmintic properties of the aqueous extracts of $C$. odorata have also been widely known among the peasant population of Asia and Africa. Its popularity as an effective therapy against diarrhea, malaria fever, tooth ache, diabetes, skin diseases, dysentery and colitis has been severally documented $[43,44]$.

Newbouldia laevis (P. Beauv.) of family, Bignoniaceae, commonly called African border tree or boundary tree is known locally as "Aduruku" in Hausa, "Ogirisi” in Igbo and "Akoko" in Yoruba Languages of Northern, Eastern and Western Nigeria, respectively.

The plant is valued for many medicinal properties in various African tropical catalogues. Extracts from different parts of the plant (leaves, stem, bark and roots) have been shown to possess antimicrobial, antimalaria, antioxidant, nociceptive and anti-inflammatory properties $[45,46]$. The aqueous and ethanol leaf extracts displayed uterine contractile effects [47].

Plant extracts have been used to control yam diseases [12]. It is important to search for a method of controlling yam deterioration that will be affordable, durable and environment friendly.

This study investigated the antifungal properties of leaf extracts of Cymbopogon citratus, Chromolaena odorata and Newbouldia laevis against some spoilage fungi responsible for the deterioration of water yam.

\section{Materials and methods}

\section{Sources of materials}

Water yams (Dioscorea alata L.) with symptoms of post-harvest rot were obtained from yam barn of National Root Crops Research Institute, Umudike. Fresh healthy water yams were collected from the same barn. Based on previous biological activities, leaves of Cymbopogon citratus, Chromolaena odorata and Newbouldia laevis were used. Cymbopogon citratus and Newbouldia laevis were collected from Okpuno, Awka while Chromolaena odorata was collected from National Root Crops Research Institute, Umudike. The botanical identities of the plants were authenticated by the Horticulture unit of National Root Crops Research Institute, Umudike, Abia State, Nigeria.

\section{Sterilization of materials}

All the equipment was sterilized according to the methods described by [48-51]. The glass wares were surface sterilized (to remove surface contaminants) with $70 \%$ ethanol and thoroughly rinsed with sterile distilled water. They were placed in racks to dry and were packed into the autoclave for sterilization at a temperature of $121^{\circ} \mathrm{C}$ for 15 minutes at 15 psi.

\section{Preparation of culture media}

The culture media that was used for fungal growth and maintenance is Potato Dextrose Agar (PDA). The PDA was prepared according to manufacturer's recommendation by dissolving $39 \mathrm{~g}$ of PDA powder in one liter of distilled water in a $1000 \mathrm{ml}$ round bottom flask. It was swirled and boiled to melt in a heater. It was sterilized with an autoclave at a temperature of $121^{\circ} \mathrm{C}$ for 15 minutes. The medium was allowed to cool to $47^{\circ} \mathrm{C}$ after which was poured into sterile plates (Petri dishes) and allowed to be solidified.

\section{Isolation of fungal pathogens from rotten water yams}

The Petri dishes were inoculated with water yam samples by cutting sections of approximately $2 \mathrm{~mm}$ cubes from the tissue at the junction between healthy and infected portion of the water yams with 
surface sterilized blade. They were surface sterilized (to remove surface contaminants) in $70 \%$ ethanol and then rinsed twice (one minute each wash) in sterile distilled water (SDW). The cut pieces of water yams were placed on sterile paper towels in a Laminar Airflow Hood Chamber for 10 minutes to dry and then placed onto PDA. The plates were incubated at $27^{\circ} \mathrm{C}$ for four days and then examined daily for the development of fungi growth.

\section{Sub-culturing/purification and identification of test fungi pathogens}

When growth has established, subcultures were prepared using inocula from different organisms in the mixed cultures to obtain a pure culture. This was done by transferring hyphal tips from the colony edge of the mixed cultures to fresh plates of PDA using flame sterilized blades. After sub-culturing, the plates were incubated at $27^{\circ} \mathrm{C}$ until pure cultures were obtained. The Petri dishes of pure cultures of the test fungi were then sealed with paraffin to prevent contamination. The resulting pure cultures were used for characterlization and subsequent identification of the fungi isolates with the aid of a compound microscope and identification guides [52,53].

\section{Pathogenicity test}

This test was carried out by using microorganisms from the rotten samples. Fresh healthy water yams were first washed with tap water and then surface sterilized with $70 \%$ ethanol solution. The washed yams were placed on sterile paper towels and allowed to dry for 12 minutes in a Laminar Airflow Hood. Sterile cork borer ( $5 \mathrm{~mm}$ diameter) was used to bore holes in the water yams. The parts of the water yams which were bored out at each point were kept in sterile dishes.

An agar block measuring $4 \mathrm{~mm}$ by $4 \mathrm{~mm}$ from growing cultures of each test isolates (pure cultures) was inoculated into the hole made with the aid of another cork borer ( $4 \mathrm{~mm}$ diameter). After the inoculation, the parts of the yam bored out was carefully replaced and sealed with sterile blue seal Vaseline to prevent contamination and labeled accordingly. A control experiment which had no isolate was set up (inoculated with agar plugs alone).

After inoculating the entire test isolates into their respective healthy yams, all the yams were incubated for 6 days in a humidity chamber. The yams were examined daily for evidence of rot such as softening, discolouration and offensive odour. At the end of the 6 days incubation period, the yams were carefully cut open along the line of incubation to expose the inner regions of the yams which was examined for rot. Where possible the length and girth of the rot area and those of the entire yams were measured with transparent ruler and recorded.

\section{Preparation of plant extracts}

The fresh leaves of Cymbopogon citratus, Chromolaena odorata and Newbouldia laevis were thoroughly washed with tap water and then with sterile distilled water (SDW) and were sundried for 5 days for milling. The dried samples were separately ground in a Laboratory Mill (Thomas Wiley model ED-5 made in USA) after which the ground samples were sieved to obtain powdered processed sample used for the extraction.

Using cold solvent extraction method [54-56]. 10 g, 20 g, 30 g, 40 $\mathrm{g}$ and $50 \mathrm{~g}$ portion of each processed samples were mixed with $100 \mathrm{ml}$ of each solvent (aqueous and ethanol) separately in a bottle to produce $10 \%, 20 \%, 30 \%, 40 \%$ and $50 \%$ extract concentrations respectively. The extracts were sieved through with four layers of sterile cheese cloth and stored in sterile conical flask which were later used for mycelia growth inhibition.

\section{Effect of plant extracts on fungal growth}

Effect of plant extract on mycelia growth with test fungi was studied using the food poisoning techniques [11]. One milliliter of each plant extract concentrations $(10 \%, 20 \%, 30 \%, 40 \%$ and $50 \%)$ was dispensed per Petri dish and $9 \mathrm{ml}$ of the media (molten PDA) was added to each of the Petri dish containing extract and carefully spread evenly over the plate. These were used for the inhibition of mycelia growth. The plates were gently rotated to ensure even dispersion of the extracts. The agar extract mixture was allowed to solidify and then inoculated at the center with a $4 \mathrm{~mm}$ diameter mycelia disc obtained from the colony edge of 7-day old pure cultures of test fungi. Each treatment was duplicated. The control set up consists of blank agar plate (no extract) inoculated with the test fungi as described above.

All the plates were incubated at $27 \pm 2^{\circ} \mathrm{C}$ for 5 days and examined daily for growth and presence of inhibition. Colony diameter was taken as the mean growth along two directions on two pre-drawn perpendicular lines on the reverse side of the plates. The effectiveness of the extract was recorded in terms of percentage inhibition, which was calculated according to the methods described by Whips.

Percentage inhibition $=\frac{R_{1}-R_{2}}{R_{1}} \times \frac{100}{1}$

Where $R_{1}$ is the farthest radial distance of pathogen in control plates, while $R_{2}$ is the farthest radial distance of pathogen in extract incorporated agar plates.

The inhibition percentage was determined as a guide in selecting the minimum inhibition concentration (MIC) that will be effective in controlling the rot-causing fungi. Extracts were rated for their inhibitory effects using the scale of Sangoyomi [11].

$$
\begin{aligned}
& \leq 0 \%=\text { no inhibition } \\
& >0-20 \%=\text { slight inhibition } \\
& >20-50 \%=\text { moderate inhibition } \\
& >50-100 \%=\text { effective inhibition } \\
& 100 \%=\text { high inhibition }
\end{aligned}
$$

\section{Phytochemical analysis}

Some portions of the dried, ground leaves of Cymbopogon citratus, Chromolaena odorata, Newboludia laevis were subjected to phytochemical screening using standard methods [54,57-59], for the presence of alkaloid, tannin, saponin and flavonoid.

\section{Determination of alkaloid using Harbone [54] method}

Five grams of the sample was weighed into a 250 -ml beaker and 200 $\mathrm{ml}$ of $10 \%$ acetic acid in ethanol was added and covered and allowed to stand for 4 hours. This was filtered, and the extract was concentrated on a water bath to one quarter of the original volume. Concentrated ammonium hydroxide was added drop-wise to the extract until the precipitation was complete. The whole solution was allowed to settle, and the precipitation was collected and washed with dilute ammonium hydroxide and then filtered. The residue is the alkaloid which was dried and weighed.

\section{Determination of tannin by Van-Burden and Robinson [57] method}

Five hundred milligram of the sample was weighed into a $50 \mathrm{ml}$ plastic bottle. $50 \mathrm{ml}$ of distilled water was added and shaken for 1 hour in a mechanical shaker. This was filtered into a $50 \mathrm{ml}$ volumetric flask 
and made up to the mark. Then $5 \mathrm{ml}$ of the filtered was pipetted out into a test tube and mixed with $2 \mathrm{ml}$ of $0.1 \mathrm{M} \mathrm{Fecl}_{3}$ in $0.1 \mathrm{NHCL}$ and $0.008 \mathrm{M}$ potassium ferrocyanide. The absorbence was measured at 120 $\mathrm{nm}$ within $10 \mathrm{~min}$.

\section{Determination of saponin}

The method used was that of Obdoni and Ochuko [58]. The samples were ground and $20 \mathrm{~g}$ of each were put into a conical flask and $10^{\circ} \mathrm{Cm}^{3}$ of $20 \%$ aqueous ethanol were added. The samples were heated over a hot water bath for 4 hours with continuous stirring at about $55^{\circ} \mathrm{C}$. The mixture was filtered, and the residue re-extracted with another 200 $\mathrm{ml}$ of $20 \%$ ethanol. The combined extracts were reduced to $40 \mathrm{ml}$ over water bath at about $90^{\circ} \mathrm{C}$. The concentrate was transferred into a 250 $\mathrm{ml}$ separatory funnel and $20 \mathrm{ml}$ of diethyl ether was added and shaken vigorously. The aqueous layer was recovered while the ether layer was discarded. The purification process was repeated. $60 \mathrm{ml}$ of n-butanol was added. The combined n-butanol extracts were washed twice with $10 \mathrm{ml}$ of $5 \%$ aqueous sodium chloride. The remaining solution was heated in a water bath. After evaporation, the samples were dried in the oven to a constant weight; the saponin content was calculated as percentage.

\section{Determination of flavonoid by the method of Boham and Kocipal-Abyazan [59]}

Ten gram of the plant sample was extracted repeatedly with 100 $\mathrm{ml}$ of $80 \%$ aqueous methanol at room temperature. The whole solution was filtered through Whatman filter paper No $42(125 \mathrm{~mm})$. The filtrate was later transferred into crucible and evaporated into dryness over a waterbath and weighed to a constant weight.

\section{Statistical analysis}

Data were analyzed using Analysis of Variance (ANOVA) via Statistical Analysis System (SAS) of Version 9.1 and means of treatment were compared using Duncan Multiple Range Test (DMRT) at $\mathrm{P}<0.05$. T-test was also used to compare the plant extracts at 0.05 significant level using statistical package for social science (SPSS Version 21).

\section{Results}

\section{Isolation of fungal Pathogens from Rotten Water Yam Samples}

The incidence of occurrence of fungi isolates associated with Dioscorea alata indicated that five fungi were isolated, and they included Botryodiplodia theobromae Pat., Aspergillus niger Van Tiegh, Fusarium solani Matt., Penicillium spp. and Rhizopus stolonifer Vuill. The results depicted that the most frequently occurring was Botryodiplodia theobromae at a frequency of $70 \%$ while the least occurring were Fusarium solani and Penicillium spp at a frequency of $1 \%$ each (Table 1).

\section{Pathogenicity test}

The fungi tested included B. theobromae, A. niger, F. solani, Penicillium spp. and $R$. stolonifer were confirmed to cause the same

Table 1. Incidence occurrence of fungi isolates associated with water yam

\begin{tabular}{|c|c|}
\hline Organism & Percentage Occurrence \\
\hline Botryodiplodia theobromae & 70 \\
\hline Aspergillus niger & 14 \\
\hline Fusarium solani & 1 \\
\hline Penicillium spp & 1 \\
\hline Rhizopus stolonifer & 14 \\
\hline
\end{tabular}

disease and rot type noticed on the rot infected sample. The fungus $B$. theobromae was the most virulent, causing $20 \%$ rot on the Dioscorea alata while the least virulent was Penicillium spp., causing $0.5 \%$ rot on Dioscorea alata (Table 2).

Effect of crude extracts of Cymbopogon citratus, Chromolaena odorata and Newbouldia laevis on the mycelia growth of the test fungi

All the plant extracts showed varying degrees of inhibition on the test fungi, this was dependent on the concentration of the extract. With respect to ethanol, Cymbopogon citratus at 50\% extract concentration showed the highest inhibitory effect of $46.00 \%$ (moderately effective) on Penicillium spp, this was significantly higher than other interactions, while the least inhibitory effects of $11.10 \%$ (slightly effective) each were recorded on Botryodiplodia theobromae at 10\% and 30\% extract concentration (Table 3). Cold water extract of Cymbopogon citratus at $50 \%$ extract concentration had the highest inhibitory effect of $39.00 \%$ (moderately effective) on Aspergillus niger, while the least inhibitory effect of $4.00 \%$ (slightly effective) was observed on Botryodiplodia theobromae at $10 \%$ extract concentration (Table 4 ).

Ethanol extracts of Chromolaena odorata at 50\% extract concentration showed the highest inhibitory effects of $41.00 \%$ (moderately effective) each on Aspergillus niger and Penicillium spp (Table 5) respectively, whereas the least inhibitory effect of $11.18 \%$ (slightly effective) was recorded on Botryodiplodia theobromae at 10\% extract concentration. Cold water extract of Chromolaena odorata at $50 \%$ extract concentration showed the highest inhibitory effect of $39.00 \%$ (moderately effective) on Aspergillus niger, whereas the least inhibitory effect of $8.00 \%$ (slightly effective) was noticed against Botryodiplodia theobromae at $10 \%$ extract concentration (Table 6).

Ethanol extract of Newbouldia laevis at 50\% extract concentration showed the highest inhibitory effect of $49.11 \%$ (moderately effective) on Penicillium spp (Table 7), whereas the least inhibitory effect of $0.35 \%$ (slightly effective) was observed on Botryodiplodia theobromae at $20 \%$ extract concentration. Cold water extract of Newbouldia laevis at $50 \%$ extract concentration showed the highest inhibitory effect of $44.01 \%$ (moderately effective) on Penicillium spp (Table 8), whereas the least inhibitory effect of $3.04 \%$ (slightly effective) was noticed against Botryodiplodia theobromae at $40 \%$ extract concentration.

Phytochemical screening of leaf extracts of $C$. citratus, $C$. odorata and N. laevis

\section{Quantitative analysis}

The quantitative assay revealed that N.laevis was the highest in alkaloid, flavonoid, saponin and tannin contents with values of $3.06 \pm 0.03,2.09 \pm 0.08,2.05 \pm 0.01$ and $2.05 \pm 0.01$ respectively (Table 9). The contents of the other phytochemicals are also shown in the table.

T-test comparison between ethanol and cold-water extracts of Cymbopogon citratus, Chromolaena odorata and Newbouldia laevis

Comparison between cold water and ethanol extracts of $C$. citratus showed that ethanol extract gave a mean percentage inhibition of $57.88 \pm 1.01$ which is significant $(\mathrm{P}<0.05)$ compared to $46.09 \pm 1.23$ of cold water extract. The mean percentage inhibition of ethanol extract of C. odorata $(62.76 \pm 1.45)$ showed a highly significant difference $(\mathrm{P}<0.05)$ from the mean percentage inhibition recorded for the cold-water extract (34.72 \pm 0.11$)$. The mean percentage inhibition of ethanol extract 
Table 2. Pathogenicity test of fungi isolated

\begin{tabular}{|c|c|}
\hline Organism & Percentage Occurrence \\
\hline Botryodiplodia theobromae & 20 \\
\hline Aspergillus niger & 10 \\
\hline Fusarium solani & 7 \\
\hline Penicillium spp & 0.5 \\
\hline Rhizopus stolonifer & 2.5 \\
\hline
\end{tabular}

Table 3. Minimum percentage inhibition of test fungi using C. citratus with ethanol extract

\begin{tabular}{|c|c|c|c|c|c|}
\hline Organism & $10 \%$ & $20 \%$ & $30 \%$ & $40 \%$ & $50^{\circ}$ \\
\hline B. theobromae & $11.10^{\mathrm{a}}$ & $13.11^{\mathrm{c}}$ & $11.10^{\mathrm{ab}}$ & $33.08^{\mathrm{ac}}$ & $39.44^{\mathrm{ab}}$ \\
\hline A. niger & $32.35^{\mathrm{ab}}$ & $33.16^{\mathrm{ab}}$ & $39.03^{\mathrm{ac}}$ & $39.71^{\mathrm{ac}}$ & $41.00^{\mathrm{cb}}$ \\
\hline F. solani & $13.11^{\mathrm{bc}}$ & $12.02^{\mathrm{bc}}$ & $11.23^{\mathrm{b}}$ & $29.65^{\mathrm{c}}$ & $43.30^{\mathrm{bc}}$ \\
\hline Penicillium spp & $17.01^{\mathrm{ac}}$ & $30.16^{\mathrm{ab}}$ & $30.03^{\mathrm{cb}}$ & $44.00^{\mathrm{ab}}$ & $46.00^{\mathrm{ab}}$ \\
\hline R. stolonifer & $13.11^{\mathrm{c}}$ & $11.12^{\mathrm{ab}}$ & $11.23^{\mathrm{b}}$ & $11.65^{\mathrm{c}}$ & $18.00^{\mathrm{bc}}$ \\
\hline
\end{tabular}

Means with the same letter in the same column are not significantly different at $\mathrm{P}<0.05$ using Duncan Multiple Range Test (DMRT)

Table 4. Minimum percentage inhibition of test fungi using C. citratus with cold water extract

\begin{tabular}{|c|c|c|c|c|c|}
\hline Organism & $10 \%$ & $20 \%$ & $30 \%$ & $40 \%$ & $50 \%$ \\
\hline B. theobromae & $4.00^{\mathrm{a}}$ & $9.00^{\mathrm{b}}$ & $13.10^{\mathrm{c}}$ & $22.00^{\mathrm{ac}}$ & $29.00^{\mathrm{ab}}$ \\
\hline A. niger & $33.88^{\mathrm{ac}}$ & $36.33^{\mathrm{ac}}$ & $29.00^{\mathrm{ab}}$ & $37.71^{\mathrm{ab}}$ & $39.00^{\mathrm{ac}}$ \\
\hline F. solani & $11.90^{\mathrm{c}}$ & $18.12^{\mathrm{b}}$ & $19.01^{\mathrm{b}}$ & $19.05^{\mathrm{b}}$ & $23.84^{\mathrm{bc}}$ \\
\hline Penicillium spp & $24.05^{\mathrm{ac}}$ & $23.00^{\mathrm{ac}}$ & $26.00^{\mathrm{ab}}$ & $24.71^{\mathrm{ab}}$ & $33.20^{\mathrm{c}}$ \\
\hline R. stolonifer & $15.76^{\mathrm{ab}}$ & $16.77^{\mathrm{ab}}$ & $19.92^{\mathrm{cb}}$ & $21.23^{\mathrm{bc}}$ & $21.00^{\mathrm{bc}}$ \\
\hline
\end{tabular}

Means with the same letter in the same column are not significantly different at $\mathrm{P}<0.05$ using Duncan Multiple Range Test (DMRT)

Table 5. Minimum percentage inhibition of test fungi using $C$. odorata with ethanol extract

\begin{tabular}{|c|c|c|c|c|c|}
\hline Organism & $10 \%$ & $20 \%$ & $30 \%$ & $40 \%$ & $50^{\circ}$ \\
\hline B. theobromae & $11.18^{\mathrm{a}}$ & $15.03^{\mathrm{b}}$ & $31.05^{\mathrm{c}}$ & $33.08^{\mathrm{ac}}$ & $39.44^{\mathrm{ab}}$ \\
\hline A. niger & $32.35^{\mathrm{ac}}$ & $33.16^{\mathrm{ab}}$ & $39.03^{\mathrm{ab}}$ & $39.71^{\mathrm{ab}}$ & $41.00^{\mathrm{ab}}$ \\
\hline F. solani & $13.11^{\mathrm{c}}$ & $12.02^{\mathrm{ab}}$ & $11.23^{\mathrm{b}}$ & $29.65^{\mathrm{c}}$ & $38.38^{\mathrm{bc}}$ \\
\hline Penicillium spp & $32.35^{\mathrm{ac}}$ & $33.16^{\mathrm{ab}}$ & $39.03^{\mathrm{ab}}$ & $39.71^{\mathrm{ab}}$ & $41.00^{\mathrm{ab}}$ \\
\hline R. stolonifer & $13.11^{\mathrm{c}}$ & $12.02^{\mathrm{ab}}$ & $11.23^{\mathrm{b}}$ & $29.65^{\mathrm{c}}$ & $38.38^{\mathrm{bc}}$ \\
\hline
\end{tabular}

Means with the same letter in the same column are not significantly different at $\mathrm{P}<0.05$ using Duncan Multiple Range Test (DMRT)

Table 6. Minimum percentage inhibition of test fungi using $C$. odorata with cold water extract

\begin{tabular}{|c|c|c|c|c|c|}
\hline Organism & $10 \%$ & $20 \%$ & $30 \%$ & $40 \%$ & $50 \%$ \\
\hline B. theobromae & $8.00^{\mathrm{c}}$ & $17.88^{\mathrm{b}}$ & $29.15^{\mathrm{c}}$ & $31.16^{\mathrm{ac}}$ & $32.10^{\mathrm{ab}}$ \\
\hline A. niger & $9.06^{\mathrm{ac}}$ & $16.33^{\mathrm{ab}}$ & $29.00^{\mathrm{ab}}$ & $37.71^{\mathrm{ab}}$ & $39.00^{\mathrm{ab}}$ \\
\hline F. solani & $16.88^{\mathrm{c}}$ & $18.12^{\mathrm{b}}$ & $19.03^{\mathrm{b}}$ & $19.05^{\mathrm{b}}$ & $25.99^{\mathrm{bc}}$ \\
\hline Penicillium spp & $21.05^{\mathrm{ac}}$ & $22.00^{\mathrm{ac}}$ & $24.00^{\mathrm{ab}}$ & $24.71^{\mathrm{ab}}$ & $30.20^{\mathrm{ab}}$ \\
\hline R. stolonifer & $14.00^{\mathrm{ab}}$ & $16.77^{\mathrm{ab}}$ & $18.00^{\mathrm{cb}}$ & $22.01^{\mathrm{cb}}$ & $21.00^{\mathrm{ac}}$ \\
\hline
\end{tabular}

Means with the same letter in the same column are not significantly different at $\mathrm{P}<0.05$ using Duncan Multiple Range Test (DMRT)

Table 7. Minimum percentage inhibition of test fungi using $N$. laevis with ethanol extract

\begin{tabular}{|c|c|c|c|c|c|}
\hline Organism & $10 \%$ & $20 \%$ & $30 \%$ & $40^{\circ} \%$ & $50 \%$ \\
\hline B. theobromae & $7.10^{\mathrm{ab}}$ & $0.35^{\mathrm{ac}}$ & $0.38^{\mathrm{ac}}$ & $6.40^{\mathrm{ac}}$ & $10.00^{\mathrm{ab}}$ \\
\hline A. niger & $9.48^{\mathrm{ab}}$ & $23.95^{\mathrm{b}}$ & $26.50^{\mathrm{c}}$ & $27.03^{\mathrm{c}}$ & $42.40^{\mathrm{bc}}$ \\
\hline F. solani & $18.66^{\mathrm{c}}$ & $13.02^{\mathrm{c}}$ & $22.90^{\mathrm{cb}}$ & $29.65^{\mathrm{c}}$ & $40.20^{\mathrm{c}}$ \\
\hline Penicillium spp & $17.01^{\mathrm{ac}}$ & $19.10^{\mathrm{a}}$ & $30.03^{\mathrm{cb}}$ & $44.00^{\mathrm{ab}}$ & $49.11^{\mathrm{bc}}$ \\
\hline R. stolonifer & $9.00^{\mathrm{c}}$ & $11.12^{\mathrm{ab}}$ & $9.77^{\mathrm{ab}}$ & $8.65^{\mathrm{c}}$ & $11.00 \mathrm{~s}^{\mathrm{bc}}$ \\
\hline
\end{tabular}

Means with the same letter in the same column are not significantly different at $\mathrm{P}<0.05$ using Duncan Multiple Range Test (DMRT)
Table 8. Minimum percentage inhibition of test fungi using $N$. laevis with cold water extract

\begin{tabular}{|c|c|c|c|c|c|}
\hline Organism & $10 \%$ & $20 \%$ & $30 \%$ & $40 \%$ & $50 \%$ \\
\hline B. theobromae & $13.22^{\mathrm{b}}$ & $12.95^{\mathrm{ac}}$ & $23.80^{\mathrm{ac}}$ & $3.40^{\mathrm{ac}}$ & $22.00^{\mathrm{ab}}$ \\
\hline A. niger & $10.33^{\mathrm{ba}}$ & $10.95^{\mathrm{ba}}$ & $26.50^{\mathrm{c}}$ & $27.03^{\mathrm{c}}$ & $42.40^{\mathrm{bc}}$ \\
\hline F. solani & $14.06^{\mathrm{c}}$ & $26.02^{\mathrm{c}}$ & $22.90^{\mathrm{c}}$ & $29.65^{\mathrm{cb}}$ & $24.20^{\mathrm{cb}}$ \\
\hline Penicillium spp & $16.00^{\mathrm{ac}}$ & $30.00^{\mathrm{a}}$ & $31.03^{\mathrm{cb}}$ & $19.00^{\mathrm{ab}}$ & $44.01^{\mathrm{bc}}$ \\
\hline R. stolonifer & $13.33^{\mathrm{c}}$ & $15.12^{\mathrm{ab}}$ & $22.01^{\mathrm{ab}}$ & $8.05^{\mathrm{c}}$ & $31.10^{\mathrm{bc}}$ \\
\hline
\end{tabular}

Means with the same letter in the same column are not significantly different at $\mathrm{P}<0.05$ using Duncan Multiple Range Test (DMRT)

Table 9. Quantitative phytochemical analysis of C. citratus, C. odorata and N. laevis

\begin{tabular}{|c|c|c|c|c|c|}
\hline Plant Extracts & Alkaloid & Flavonoid & Saponin & Tannin & T- Statistics \\
\hline C. Citratus & $-2.96 \pm 0.11_{\_}$ & $-1.72 \pm 0.11_{\_}$ & $0.06 \pm 0.05_{-}$ & $0.06 \pm 0.05_{-}$ & 0.021 \\
\hline C. Odorata & $2.00 \pm 0.11_{\_}$ & $1.06 \pm 0.01_{\_}$ & $1.03 \pm 0.77_{-}$ & $0.03 \pm 1.07_{-}$ & 0.701 \\
\hline N. laevis & $3.06 \pm 0.03_{\_}$ & $2.09 \pm 0.08_{\_}$ & $2.05 \pm 0.01_{-}$ & $2.05 \pm 0.01_{-}$ & 0.035 \\
\hline
\end{tabular}

of $N$. laevis $(48.03 \pm 2.77)$ showed a significant difference $(\mathrm{P}<0.05)$ from the mean percentage inhibition recorded for the cold-water extract (39.88 \pm 2.44$)$ (Table 10).

\section{Discussion}

The organisms associated with deterioration of water yams (Dioscorea alata L.) in this study were Botryodiplodia theobromae Pat., Aspergillus niger Van Tiegh, Fusarium solani Matt., Penicillium spp and Rhizopus stolonifer Vuill. B. theobromae was the highest in occurrence while F. solani and Penicillium spp were the least. The result of this study showed that plant extracts, Cymbopogon citratus (DC), Chromolaena odorata (L.) and Newbouldia laevis (P.Beauv.) showed antifungal activity against the test organisms above at various concentration of the plant extracts.

The inhibitory effect of ethanol and cold-water extracts of $C$. citratus, C. odorata and N. laevis at five different concentrations (10\%, $20 \%, 30 \%, 40 \%$ and $50 \%$ ) were evaluated in order to develop affordable and simpler methods of controlling deterioration of water yams. The ethanol and cold-water extracts of the plants at all the concentrations were inhibitory on the test organisms in vitro, with ethanol extract being the more potent. This is in line with observations made by Okigbo and Odurukwe [24] and that of Sangoyomi [11]. The inhibitory effect on the test fungi differs with the plant materials and solvent of extraction. Generally, the ethanol extracts were more effective than their corresponding cold-water extracts of the plant samples. This can be attributed to the fact that ethanol is an organic solvent and will dissolve organic compounds better, hence, extract, the active compounds required for anti-microbial activities. The difference in the fungitoxic potential between extractions medium can also be as a result of the different susceptibility of each of the test isolates to different concentrations of the extracts. This also agrees with the findings of some workers $[24,27,60,61]$. As the concentration of the extracts increased, the level of inhibition on the mycelial growth of the fungi increased. This agrees with the reports of Ekwenye and Elegalam, Okigbo and Igwe [62]. This is also similar to the results obtained by Suleiman [63] who stated a significant difference between mycelial growth value recorded on the various plant extracts concentration. This suggests that there is difference in the solvent soluble antifungal elements in the respective leaf extracts as reported by Iwu [42] and Sofowora [64]. B. theobromae showed slightly effective and moderately effective inhibition in all the 
Table 10. T-test comparison between ethanol and cold water extracts of C. citratus, C.odorata and $N$. laevis

\begin{tabular}{|c|c|c|c|}
\hline Plant Extracts & Cold Water & Ethanol & T- Statistics \\
\hline Cymbopogon citratus & $46.09 \pm 1.23_{-}$ & $57.88 \pm 1.01 \_$ & -1.035 \\
\hline Chromolaena odorata & $34.72 \pm 0.11_{-}$ & $62.76 \pm 1.45 \_$ & -2.00 \\
\hline Newbouldia laevis & $39.88 \pm 2.44_{-}$ & $48.03 \pm 2.77 \_$ & -2.701 \\
\hline
\end{tabular}

extract concentrations tested. This is similar to the result obtained by Sangoyomi [11] on post-harvest rot of yam but with different plant extracts. She reported slightly effective inhibition of $C$. odorata on $B$. theobromae.

According to Srinivauson, et al. [65], the presence of bioactive substances has been reported to confer resistance to fungi, bacteria and pests. This therefore, explains the demonstration of antifungal activities by the extracts used in this work. Thus, the antifungal properties of these plant extracts are probably due to the presence of phytochemicals which are antimicrobial agents [66], and inhibitory to the growth of these pathogens [67]. Phytochemical analysis of the plant extracts showed that $N$. laevis contained more phytochemicals when compared to other plant extracts which justifies its highest inhibition on the test organisms at $50 \%$ concentration. Ethanol extracts of $C$. odorata showed highest inhibition on the test organisms while ethanol extracts of $N$. laevis showed the least inhibitory effect on the test fungi.

Pharmacological and medicinal potentials of all these phytochemicals were proved by the reports of several workers [68,71].

This study reveals the fungitoxic potentials of ethanol and coldwater extracts of C. citratus, C. odorata and N. laevis at different concentrations and could be further developed to produce natural fungicides. The presence of fungicidal substances in these plant species agrees with other workers $[11,24,27]$. Hence, it could be inferred from the result obtained in this work, that both ethanol and cold-water extracts of C. citratus, C. odorata and $N$. laevis could be developed as natural fungicides in the control of microorganisms that cause the deterioration of water yams.

\section{Conclusion}

This study demonstrated that C. citratus (lemon grass), C. odorata (siam weed) and $N$. laevis (ogirisi) showed antifungal activity against the test organisms. This finding is important from the point of view of controlling diseases associated with B. theobromae, A. niger, $F$. solani, Penicillium spp and $R$. stolonifer that affects plant and animal without the use of chemicals which cause environmental pollution. The antifungal potentials of C. citratus, C. odorata and N. laevis as observed in this study therefore, raise hope in the use of natural plants to control fungi pathogens and to replace the synthetic dangerous and expensive chemicals used at present. The cooperation of mycologists, breeders, chemists, ecologists and others in the field of agriculture is necessary to achieve maximum progress in this important field of research.

\section{References}

1. Orkwor GC (1998) Yam production in Nigeria. In: J. Berthaud, N. Bricas and J. Mardand (Eds.) Yam, Old Plant and Crop for the Future. Actes du Seminaire Inter. Cirad Intra-orstom-coraf. Montpellier, France, pp: 81-85.

2. Coursey DG (1967) Yams. Longmans Green London, pp: 230.

3. Okigbo RN (2002) Mycoflora of tuber surface of white yam (Dioscorea rotundata Poir) and post harvest control of pathogens with Bacillus subtilis. Mycopathologia 156: 81-85.

4. Igbeka JC (1985) Storage practices for yam in Nigeria. Agricultural Mechanization in Asia, Africa and Latin America 16: 55-58.

5. Adeniji MO (1970a) Fungi associated with storage decay of yam in Nigeria. Phytopathology 60: 590-592.
6. Okigbo RN (2004) A review of biological control methods for post-harvest yams (Dioscorea spp.) in storage in South Eastern Nigeria. King Mongkut Technology Ladkraba Science Journal 4: 207-215.

7. Hahn SK (1995) Yams: Dioscorea spp (Dioscoreaceae) In: J. Smaartt and Simmonds, N.W (Eds) Evolution of Crop Plants. Longman Scientific and Technical, UK, pp: 112-120.

8. Udensi EA, Oselebe HO, Onuoha AU (2010) Antinutritional assessment of D. alata varieties. Pak J Nutr 9: 179-181.

9. Zhang T, Oates CG (1999) Relationship between amylase degradation and physicochemical properties of sweet potato starches. Food Chemistry 65: 157-163.

10. Shang HF, Cheng HC, Liang HY, Liu SY, Hou WC (2007) Immunostimulatory activities of yam tuber mucilages. Botany Stud 48: 63-70.

11. Sangoyomi TE (2004) Post Harvest Fungal Deterioration of Yam (Dioscorea rotundata Poir) and its control. Ph.D. Thesis. University of Ibadan, Nigeria. 179p.

12. Okigbo RN, Ogbonnaya UO (2006) Antifungal effects of two tropical plant leaf extracts (Ocimum gratissimum and Aframomum meleguata) on post-harvest yam (Dioscorea spp.) rot. African Journal of Biotechnology 5: 727-731.

13. Olayide SO, Heady EO (1982) Introduction to Agricultural Production. Ibadan University Press, Ibadan, pp: 319.

14. Coursey DG, Booth RH (1972) The post-harvest phytopathology of perishable tropical produce. Review of Plant Pathology 51: 751-765.

15. National Root Crops Research Institute (1983) Rapid multiplication of seed yam by minisett technique. Advisory Bulletin No. 9. NRCRI, Umudike, Nigeria.

16. Ikotun $\mathrm{T}$ (1983 b) Reduced germinability of yam setts caused by microbial deterioration. Fitopathologia Brass 8: 455-461.

17. Arene OB, Nwankiti AO, Okafor N (1985) The chemical basis of the pathology of yam tuber In: Osuji, G (Ed.) Advances in yam Research. The Biochemistry and Technology of the yam tuber. Biochemical Society of Nigeria. Anambra State University of Technology, Nigeria, pp: 251-258.

18. Okigbo RN, Ikediugwu FEO (2000) Studies on biological control of post-harvest rot in yams (Dioscorea spp.) using Trichoderma viride. Journal of Phytopathology 148: 351-355.

19. Okigbo RN (2005) Biological control of postharvest fungal rot of yam (Dioscorea spp.) withBacillus subtilis. Mycopathologia 159: 307-314. [Crossref]

20. Lai PK, Roy J (2004) Antimicrobial and chemopreventive properties of herbs and spices. Curr Med Chem 11: 1451-1460. [Crossref]

21. Azebaze AG, Meyer M, Valentin A, Nguemfo EL, Fomum ZT, et al (2006) Prenylated xanthone derivatives with antiplasmodial activity from Allanblackia monticola STANER L.C. Chem Pharm Bull (Tokyo) 54: 111-113. [Crossref]

22. Tapsell LC, Hemphill I, Cobiac L, Patch CS, Sullivan DR, et al (2006) Health benefits of herbs and spices: the past, the present, the future. Med J Aust 185: S4-24. [Crossref]

23. Rigiano D, Formisano C, Senatore F, Piacente S, Pagano E, et al. (2013) Intestinal antispasmodic effects of Helichrysum italicum (Roth) Don and chemical identification of the active ingredients. Journal of Ethnopharmacology 50: 901-906.

24. Okigbo RN, Odurukwe CN (2009) Occurrence and control of fungal rot pathogen of yam (Dioscorea rotundata Poir) with leaf extracts of Chromolaena odorata, Carica papaya and Aspilia Africana. Nigerian Journal of Mycology 2: 154-165.

25. Okigbo RN, Enweremadu EC, Agu KC, Irondi CR, Okeke CB, et al. (2015) Control of white yam (Dioscorea rotundata) rot pathogen using peel extract of water yam (Dioscorea alata). Advances in Applied Science Research 6: 7-13.

26. Akueshi CO, Kadir CO, Akueshi EU, Agina SE, Ngurukwem C (2002) Antimicrobial potential of Hyptis sauvedens Poit (Lamiaccae). Nigerian Journal of Botany 15: 37-41.

27. Okigbo RN, Nmeka IA (2005) Control of yam tuber rot with leaf extracts of Xylopia aethiopica and Zingiber officinale. African Journal of Biotechnology 4: 804-807.

28. Okigbo RN, Omodamiro OD (2006) Antimicrobial effect of leaf extracts of pigeon pea (Cajanus cajan (L.) Millsp) on some human pathogens. Journal of Herbs Species and Medicinal Plants 12: 117-127.

29. Francisco V, Figueirinha A, Neves BM, Garcia-Rodriguez C, Lopes MC, et al. (2011) Cymbopogon citratus as source of new and safe anti-inflammatory drugs: Bio-guided assay using lipopolysaccharide-stimulated macrophages. Journal of Ethnopharmacology 133: 818-827.

30. Adeneye AA, Agbaje EO (2007) Hypoglycemic and hypolipidemic effects of fresh leaf aqueous extract of Cymbopogon citratus Stapf. in rats. J Ethnopharmacol 112: 440-444. [Crossref] 
31. Fingueirinha A, Paranhos A, Perez-Alonso JJ, Santos-Buelga C, Batista MT (2008) Cymbopogon citratus leaves: Characterization of flavonoids by HPLC-PDA-ESI MS/MS and an approach to their potential as a source of bioactive polyphenols. Food Chemistry 110: 718-728.

32. Sawyerr E (1982) Traditional medicine in Sierra Leone- a critical appraisal. Nigeria Journal of Pharmacy 13: 28-33.

33. Viana GS, Vale TG, Pinho RS, Matos FJ (2000) Antinociceptive effect of the essentia oil from Cymbopogon citratus in mice. J Ethnopharmacol 70: 323-327. [Crossref]

34. Negrelle RRB, Gomes EC (2007) Cymbopogon citratus (DC.) Stapf: chemical composition and biological activities. Revista Brasileira de Plantas Medicinais 9: 80-92.

35. Bachiega TF, Sforcin JM (2011) Lemongrass and citral effect on cytokines production by murine macrophages. J Ethnopharmacol 137: 909-913. [Crossref]

36. Phan TT, Wang L, See P (2001) Phenolic compounds of Chromolaena odorata protect cultured skin cells from oxidative damage: implication for cutaneous wound healing. Biological and Pharmaceutical Bulletin 24: 1373-1379.

37. Zachariades C, Day M, Muniappan R, Reddy GVB (2009) Chromolaena odorata (L.) King and Robinson (Asteraceae). In: Muniappan, R. (Ed.). Biological Control of Tropical Weeds Using Arthropods. Cambridge University Press, Cambridge, UK, pp: $130-162$.

38. Uyi OO, Igbinosa IB (2013) The status of Chromolaena odorata and its biocontrol in West Africa. In: Zachariades, C. Strathie, L.W, day, M.D. and Muniappan, R. (Eds.). Proceedings of the Eight International Workshop on Biological Control and Management of Chromolaena odorata and other Eupatorieae. Nairobi, Kenya, 1-2 November 2010. ARC-PPRI, Pretoria, South Africa. pp: 86-98.

39. Irvens GW (1974) The problem of Eupatorium odoratum (L.) in Nigeria. Pest Articles and News Summaries 20: 76-82.

40. Zachariades C, Strathie LW, Retief E, Dube N (2011) Progress towards the biological control of Chromolaena odorata (L.) R.M. King and H. Rob (Asteraceae) in South Africa. In: Moran, V.C. Hoffmann, J.H, Hill, M.P. (Eds). Biological Control of Invasive Allien Plants in South Africa (1999-2010). African Entomology 19: 282-302.

41. Timbilla JA, Zachariades C, Braimah H (2003) Biological control and management of the alien invasive shrub, Chromolaena odorata I Africa. In: Neuenschwander, P, Borgemeister, C, Langewald, J. (eds). Biological Control in IPM Systems in Africa. CAB International, London, pp: 145-160.

42. Iwu MM (1993) Handbook of Africa Medicinal Plants from Nigeria. University of Lagos Press, Lagos, Nigeria, pp: 181-182.

43. Odugbem T (2006) Outlines and pictures of medicinal plants from Nigeria. University of Lagos Press, Lagos, Nigeria, pp: 1-283.

44. Akinmoladun AC, Akinloye O (2007) Effect of Chromolaena odorata on hypercholesterolemia-related metabolic imbalances. Proc. Akure-Humbold Kellog/3rd SAAT Annual Conference, FUTA, Nigeria, 16-19 April 2007, pp: 287-290.

45. Gafner S, Wolfender JL, Nianga M, Hostettmann K (1997) Phenylpropanoid glycosides from Newbouldia laevis roots. Phytochemistry 44: 687-690. [Crossref]

46. Akunyili DN (2000) Anticonvulsant activity of the Ethanolic Extract of Newbouldia laevis. A paper delivered at the 2nd National Association for the Advancement of Psychoanalysis (NAAP) conference held in Zaria, Nigeria. 2000, pp: 155-158.

47. Bafor E, Sanni U (2009) Uterine contractile effects of the aqueous and ethanol leaf extracts of Newbouldia laevis (Bignoniaceae) in vitro. Indian Journal of Pharmacology 71: 124-127.

48. Postagate J (1992) Microbes and Man. 3rd edition. Cambridge University Press, pp: 906.

49. Singleton P (1997) Bacteria Biology, Biotechnology and medicine (4th edition). Spectrum Books, Ibadan, Nigeria, pp: 289.
50. Cheesbrough M (2000) Medical Laboratory Manual for Tropical Countries Microbiology. Linacre House Jordan Hill, Oxford, pp: 260.

51. Jawetz M, Adelberg BGF, Brutel JS, Morse SA (2004) Medical Microbiology (3rd ed.) Megraw-Hill companies, Inc. Singapore, pp: 818.

52. Sulton BC (1980) The Coelomycetes Fungi Imperfecti with Pycinidia acervuli and stromata. Common Wealth Mycological Institute, Kew, Surrey, England. pp: 696.

53. Barnett HL, Hunter BB (1987) Illustrated General of Imperfect Fungi (4th Edition) Burgress Publishing Company, pp: 218.

54. Harbone JB (1973) Phytochemical methods. London. Chapman and Hall, Ltd, pp: 49-188.

55. Juanid SA, Olabode AO, Owuliri FC, Orkworlu AEJ, Agina SE (2006) The antimicrobial properties of Ocimum gratissimum extract on some selected bacterial gastrointestinal isolates. African Journal of Biotechnology 5: 2315-2321.

56. Doughari JH, Elmahmood AM, Manzara S (2007) Studies on the antibacterial activity of root extracts of Carica papaya L. African Journal of Microbiology Research 1: 37-41.

57. Van-Burden TP, Robinson WC (1981) Formation of complexes between protein and tannin acid. Journal of Agricultural and Food Chemistry 1: 77.

58. Obdoni BO, Ochuko PO (2001) Phytochemical studies and comparative efficacy of the crude extracts of some Homostatic plants in Edo and Delta States of Nigeria. Global Journal of Pure and Applied Sciences 8b: 203-208.

59. Boham BA, Kocipai-Abyazan R (1974) Flavonoids and condensed tannins from leaves of Hawaiian vaccinium vaticulatum and V. calycinium. Pacific Science 48: 458-463.

60. Amadioha AC (2000) Fungitoxic effects of some leaf extracts against Rhizopus oryzae causing tuber rot potato. Archives of Phytopathology 34: 1-9.

61. Onifade AK (2002) Antifungal effect of Azadirachta indica A. Juss. extracts on Collectoricum lindemathianum. Global Journal of Pure and Applied Science 6: 423-428.

62. Okigbo RN, Igwe DI (2007) The antimicrobial effects of Piper guineense "Uziza" and Phyllantus "ebe benizo" on Candida albica and Streptococcus faecalis. Acto Microbiological et Immunologica Hungarica 54: 353-366.

63. Suleman MN (2010) Fungitoxic activity of neem and pawpaw leaf extracts on Alternaria solani, causal organism of yam rots. Advances in Environmental Biology 4: 159-161.

64. Sofowora A (1997) Medicinal Plants used in Traditional Medicine in Africa. First ed. John Wiley and Sons, New York, pp: 128-129.

65. Srinivauson D, Perumalsamy LP, Nathan ST (2001) Antimicrobial activity of certain Indian medicinal plants used in folkloric medicine. Journal of Ethnopharmacology 94 217-222.

66. Okwu DE, Joshia C (2006) Evaluation of the chemical composition of two Nigerian medicinal plants. African Journal of Biotechnology 5: 361 .

67. Okigbo RN, Eme UE, Asiedu R, Ramesh P (2009b) Effect of crude extracts of Allium sativum Linn, Cymbopogon citratus (DC) Stapf and Terminalia catappa on rot causing fungi of Dioscorea species. Nigerian Journal of Botany 22: 359-369.

68. Caragay AE (1992) Cancer preventive foods and ingredients. Food Technology 46 65-69.

69. Okwu DE (2004) Phytochemicals and vitamin content of indigenous species of South Eastern Nigeria. Journal of Sustainable African Environment 6: 30-34.

70. Okigbo RN, Ajalie AN (2005) Inhibition of some human pathogens with tropical plan extracts: Chromolaena odorata and Citrus aurantifolia and some antibiotics. Journal of Molecular Medicine and Advance Science 1: 34-40.

71. Okigbo RN, Anuagasi CL, Amadi JE, Ukpabi UJ (2009) Potential inhibitory effects of some African tuberous plant extracts on Escherichia coli, Staphylococcus aureus and Candida albican. International Journal of Integrative Biology (IJIB) 6: 91-98.

Copyright: (C2017 Okigbo RN. This is an open-access article distributed under the terms of the Creative Commons Attribution License, which permits unrestricted use, distribution, and reproduction in any medium, provided the original author and source are credited. 